\title{
Pengembangan Wisata Edukasi Sampah Berbasis Komunitas di Kelurahan Sorosutan, Yogyakarta
}

\author{
Haryati Bawole Sutanto \\ Fakultas Bioteknologi, Universitas Kristen Duta Wacana \\ Jl. DR. Wahidin 5-25, Yogyakarta \\ haryati@staff.ukdw.ac.id
}

\begin{abstract}
Abstrak-Berdasarkan prediksi data dari Bank Dunia permasalahan sampah akan menjadi masalah yang sangat besar, apabila tidak dilakukan antisipasi penanganannya. Di Indonesia permasalahan sampah menjadi tantangan besar yang mutlak harus diatasi oleh kota-kota yang semakin hari semakin berkembang. Salah satu strategi penanganan sampah adalah menjadikan sampah sebagai sahabat dalam kehidupan sehari-hari umat manusia. Secara umum sampah dapat dibedakan menjadi sampah padat dan cair. Dengan mengelola sampah secara terintegrasi paradigma sampah sabagai sahabat manusia dapat diwujudkan. Permasalahan sampah tidak bisa lepas dari kehidupan manusia di kota-kota besar termasuk di Yogyakarta. Kelurahan Sorosutan adalah salah satu wilayah di Kemantren Umbulharjo, Yogyakarta yang beberapa penggerak masyarakatnya mempunyai pemikiran inovatif untuk menjadikan sampah sebagai sahabat dalam kehidupan mereka. Tujuan kegiatan pengabdian masyarakat yang dilakukan untuk memberikan pendampingan perencanaan pengembangan wisata edukasi sesuai permohonan dari kelurahan Srosutan. Strategi pengembangan wisata edukasi sampah digali dari masyarakat secara partisipatif dengan pendekatan teknis pengolahan limbah, desain Arsitektural, serta proses pemberdayaan masyarakat secara terintegrasi. Masyarakat diajak terlibat sejak awal proses, dimulai dari kegiatan identifikasi permasalahan dan potensi, identifikasi alternatif pilihan sampai keputusan atau pilihan tindakan. Kegiatan pendampingan sudah sampai ditahap identifikasi alternatif pilihan dengan intervensi dari luar berupa ilmu pengetahuan yang diharapkan dapat menambah wawasan masyarakat dan rasa percaya diri untuk mengambil keputusan secara mandiri. Proses pendampingan yang disadari membutuhkan waktu yang panjang masih berjalan sampai saat ini. Tahap pengambilan keputusan / pilihan tindakan masih dalam proses.
\end{abstract}

Kata kunci- Partisipasi, Pemberdayaan, Pengelolaan Terintegrasi, Sampah, Wisata Edukasi.
Abstract-Based on the prediction of the data from the World Bank, the waste problem will become a very big problem, if it is not handled properly. In Indonesia, the waste problem is a big challenge that absolutely must be overcome by cities that are growing day by day. One strategy for handling the waste is to make it a friend in the daily life. In general, waste can be divided into wastewater and solid waste. By managing the waste in an integrated system, the paradigm of waste as a human friend can be realized. The problem of waste cannot be separated from human life in big cities, including in Yogyakarta. Sub-district Sorosutan is one of the areas in District Umbulharjo, Yogyakarta in which several community initiators have innovative ideas to make waste as a friend in their lives. The purpose of the community service activities carried out is to provide an assistance in planning the development of educational tourism according to the request from the Sub-district Sorosutan. The strategy for developing waste education tourism is elaborated by the community in a participatory manner with a technical approach to waste management, architectural design, and an integrated community empowerment process. The community is invited to be involved from the beginning of the process, starting from identifying problems and potentials, identifying alternative options until the decision or the choice of action. The activities of the assistance have reached the stage of identifying alternative options with external intervention in the form of knowledge which is expected to increase the public insight and confidence to make decisions independently. The accompaniment process, which is realized to take a long time, is still ongoing. The decision / choice of action stage is still in progress.

Keywords - Educational Tourism, Empowerment, Integrated Management, Participation, Waste. 
Standar hidup yang semakin meningkat menyebabkan jumlah limbah yang dihasilkan juga semakin meningkat. Hal ini pada akhirnya membuat pembuangan limbah menjadi lebih sulit. Selama 50 tahun terakhir pengolahan limbah telah dikembangkan. Selain itu, pengumpulan sampah, pembakaran, penimbunan dan pengolahan air limbah menjadi praktek umum yang dilakukan di dunia industri. Sejalan dengan peningkatan apresiasi terhadap pemeliharaan kualitas lingkungan, kekuatiran mengenai pengelolaan dan pembuangan limbah juga semakin meningkat. Setiap negara berusaha untuk menerapkan sistem pengelolaan pembuangan limbah dan pemanfaatan sumber daya yang lebih efisien. [1]

Golomeova et al. [2] mengatakan bahwa sampah didefinisikan sebagai zat atau bahan yang tidak dapat digunakan atau tidak diinginkan, bisa dalam bentuk padat cair atau gas. Limbah padat merupakan istilah yang biasa digunakan untuk menggambarkan bahan non-cair yang berasal dari domestik, pertanian dan kegiatan industri, atau juga dari layanan publik. Hal ini sama dengan pengertian limbah yang tertulis dalam Peraturan Pemerintah Republik Indonesia No. 101 tahun 2014, bahwa limbah adalah sisa suatu usaha dan /atau kegiatan. [3] Untuk membedakan limbah yang berbentuk cair, sisa kegiatan sehari-hari manusia dan/atau proses alam yang berbentuk padat disebut sampah. [4].

Pemerintah Indonesia melihat bahwa pertambahan penduduk dan perubahan pola konsumsi masyarakat menimbulkan bertambahnya volume, jenis dan karakter sampah yang semakin beragam. Permasalahan sampah menjadi permasalahan nasional sehingga pengelolaannya perlu dilakukan secara komprehensif dan terpadu dari hulu ke hilir agar memberikan manfaat secara ekonomi, sehat bagi masyarakat dan aman bagi lingkungan serta dapat mengubah perilaku masyarakat.

Peran serta semua sektor dan kesadaran masyarakat sangat diperlukan dalam pengelolaan sampah. Peran sektor informal juga memberi kontribusi yang besar bagi proses daur ulang. Setiap pihak memiliki peran penting masingmasing dalam proses pengelolaan sampah. [5] Seperti yang dijelaskan oleh Golomeova [2] pengelolaan sampah tingkat lanjut dapat digambarkan dalam bentuk hirarki pengelolaan sampah (gambar 1). Tujuan penggambaran hirarki ini untuk dapat memberikan gambaran aplikasi pemanfaatan produk semaksimal mungkin dan menghasilkan limbah seminimal mungkin.

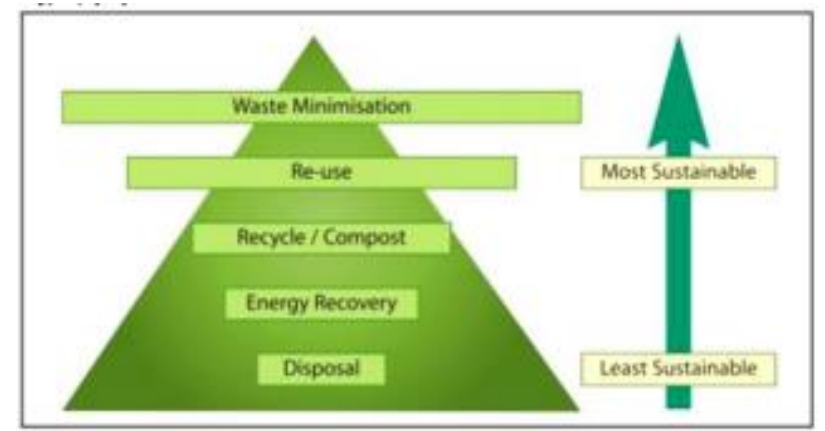

Gambar 1. Hirarki prioritas dibidangpengelolaan sampah

Penggerak masyarakat kelurahan Sorosutan memiliki inovasi untuk dapat menjadikan sampah sebagai sebuah potensi di wilayah mereka dan mengajukan gagasan untuk membuat sebuah taman wisata edukasi yang berkaitan dengan pengelolaan sampah.

\section{KONDISI UMUM KELURAHAN SOROSUTAN}

Kelurahan Sorosutan merupakan salah satu kelurahan dari 7 kelurahan di Kemantren Umbulharjo, dengan luas wilayah 175 Ha. Kelurahan Sorosutan, sesuai dengan dokumen Rencana Pengembangan Lingkungan Permukiman (RPLP) Kelurahan Sorosutan Kecamatan Umbulharjo ditetapkan tahun 2016 [6], berada pada ketingian $\pm 114 \mathrm{~m}$ di atas permukaan laut, mendapatkan curah hujan 2.012,00 mm dengan kelembaban rata-rata sebesar $24,70^{\circ}$ C. Pembagian administrasi wilayah Kelurahan Sorosutan terdiri dari 7 Rukun Kampung (RK) dengan 18 Rukun warga (RW) dan 70 Rukun Tetangga (RT). Menanggapi permohonan untuk dapat mendampingi program pengembangan kelurahan Sorosutan, khususnya rencana pembangunan taman edukasi sampah sorosutan (TESS), kegiatan pendampingan masyarakat dilakukan sejak Desember 2020.

\section{IDENTIFIKASI PERMASALAHAN DAN POTENSI}




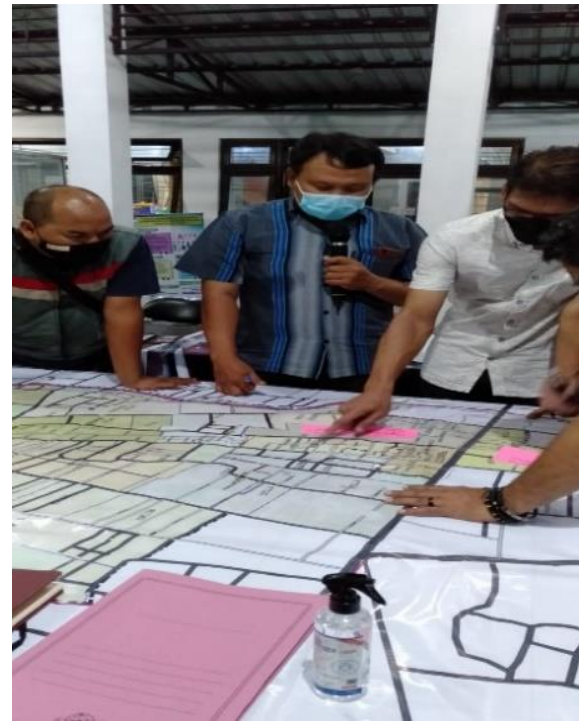

Gambar 2. FGD diadakan di setiap wilayah RK untuk menjaring gagasan alternatif solusi dari masyarakat. Sumber : Dokumentasi Pribadi

Focus Group Discusion (FGD) yang diadakan disetiap Rukun kampung (RK) dan dihadiri oleh perwakilan masyarakat, bertujuan untuk dapat mendiskusikan dan mengidentifikasikan permasalahan dan potensi yang dimiliki di setiap lingkungan tempat tinggal masyarakat. Sebelum FGD diselenggarakan, survey lapangan dikombinasikan dengan wawancara diadakan untuk menjadi materi yang akan dipaparkan saat FGD berlangsung. Hasil temuan di lapangan akan disinkronisasi dan didiskusikan dengan masyarakat di wilayah tersebut. Diharapkan pada tahap ini masyarakat dapat menemukan setiap potensi yang dimiliki, sekaligus menyadari permasalahan yang ada di masing-masing wilayah tempat tinggal yang bersangkutan. Setiap peserta sebagai penghuni wilayah di kelurahan Sorosutan diberi kesempatan untuk menyampaikan ide solusi yang dianggap dimungkinkan untuk diterapkan.

Pendapat Zaman [7] yang menyatakan bahwa sampah tidak lagi diperlakukan sebagai barang yang tidak bernilai, sehingga di masa sekarang ini sampah lebih dianggap sebagai sumber daya, sangat mendukung ide tentang pembangunan Taman Edukasi Sampah Sorosutan (TESS). Gagasan tersebut dilontarkan dengan mempertimbangkan sampah yang dihasilkan oleh masyarakat di kelurahan Sorosutan dapat menjadi potensi yang dapat dikembangkan dan menjadi alternatif peningkatan ekonomi sebagai sumber pendapatan dari sektor pariwisata di kelurahan tersebut.

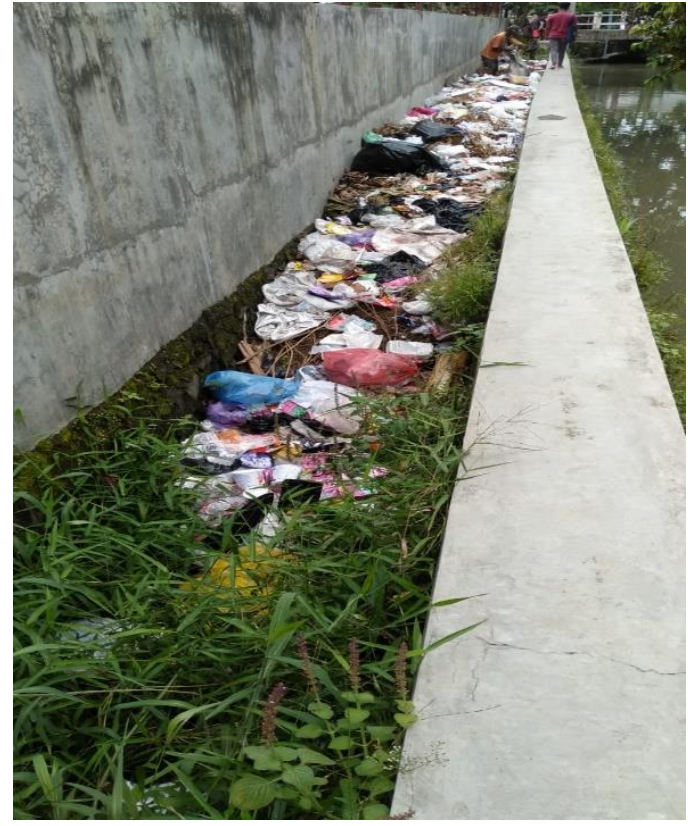

Gambar 3. Hasil survey menunjukan masih adanya masyarakat yang memanfaatkan lahan yang berbatasan dengan sungai sebagai tempat membuang sampah

Sumber : Dokumentasi Pribadi

Dari beberapa kali pertemuan dan diskusi bersama perwakilan dan pengurus masyarakat kemudian disadari bahwa limbah yang dihasilkan tidak hanya berupa limbah padat yang disebut sampah melainkan juga berupa limbah cair, yang berdasarkan hasil temuan di lapangan dan sesuai dengan dokumen RPLP penanganan limbah cair masih harus diperbaiki. Diskusi-diskusi berikutnya mengarah pada usaha untuk merancang suatu taman edukasi yang mengolah sisa kegiatan masyarakat di kelurahan sorosutan baik yg berbentuk padat (sampah) dan berbentuk cair (limbah cair).

\section{IDENTIFIKASI ALTERNATIF PILIHAN}

Sejak awal proses disepakati oleh pengurus masyarakat bahwa untuk mewujudkan gagasan pembentukan taman Edukasi harus melibatkan partisipasi masyarakat, sehingga keputusan yang ada berbasis masyarakat. Pemberdayaan dan partisipasi menjadi pusat perhatian sejak proses dimulai. Intervensi dari luar dalam hal ini dari Perguruan Tinggi, sesuai surat permohonan untuk ikut mendampingi proses perencanaan dan Perancangan Master Plan Kelurahan Sorosutan, bertujuan untuk dapat memunculkan proses transfer Ilmu Pengetahuan untuk mereka yang membutuhkan, supaya dapat menyiapkan diri sekaligus memiliki pengetahuan dan ketrampilan untuk dapat menjadi mandiri.

Supaya rancangan yang dihasilkan benar-benar berbasis masyarakat, diberikan beberapa alternatif system penangan sampah dan limbah cair, sehingga masyarakat memiliki 
kesempatan untuk mempertimbangkan system yang cocok sesuai potensi yang dimiliki. Workshop diberikan untuk menambah pengetahuan tentang system pengolahan limbah (cair) dan langkah-langkah yang perlu dipertimbangkan untuk mengaplikasikan suatu system pengolahan limbah.

Stefanakis [8] menyatakan bahwa pengolahan air limbah yang tidak tepat dan tidak memadai tidak hanya mengakibatkan pencemaran sumberdaya air dan merusak ekosistem, tetapi juga dapat menimbulkan resiko kesehatan masyarakat yang signifikan. Sebaliknya air limbah yang diolah dengan benar dapat dipertimbangkan menjadi sumber air yang baru untuk mengatasi keterbatasan ketersediaan sumber daya air.

Workshop di Kelurahan Sorosutan diadakan bersama pengurus dan perwakilan masyarakat untuk memperkenalkan dan memberi pengetahuan tentang beberapa alternatif system pengolahan limbah beserta kelebihan dan kekurangan masing-masing system. Workshop ini diadakan dengan tujuan bahwa pada akhirnya masyarakat sendiri yang akan memutuskan system pengolahan dan pengelolaan secara mandiri setelah mendapatkan pengetahuan. Masyarakat akan memahami dan memiliki kemampuan untuk mempertimbangkan sesuai dengan daya dukung, sumberdaya alam dan sumberdaya manusia yang dimiliki.

Proses pengolahan air limbah yang dikembangkan di negara-negara maju yang secara tekonologi sudah maju menggunakan mekanisasi tinggi atau energi yang besar, bukan saja tidak cocok bila ditinjau dari segi keuangan, tetapi juga kemungkinan tidak cocok di aplikasikan di wilayah lain.

Alternatif system yang cocok dan sesuai untuk Indonesia sudah banyak diteliti. Demikian juga seri penelitian yang sudah dikerjakan oleh penulis dengan menggunakan system Constructed Wetland (CW) dapat menjadi altenatif system pengolahan yang murah dan sederhana yang cocok ditempatkan untuk wilayah dengan kondisi padat penduduk telah dilakukan dengan tingkat efisiensi penghilangan polutan yang terkandung dalam limbah domestik sangat tinggi $(>50 \%)$, seperti tercantum pada table I. dibawah ini.

Tabel I.

Efisiensi penghilangan polutan limbah domestik menggunakan system CW [9]

\begin{tabular}{|l|c|}
\hline \multicolumn{1}{|c|}{ Parameter } & $\begin{array}{c}\text { Efisiensi penurunan } \\
(\boldsymbol{\%})\end{array}$ \\
\hline $\mathrm{pH}$ & - \\
\hline $\mathrm{Suhu}\left({ }^{\circ} \mathrm{C}\right)$ & - \\
\hline $\mathrm{TSS}(\mathrm{mg} / \mathrm{l})$ & 93,48 \\
\hline
\end{tabular}

\begin{tabular}{|l|c|}
\hline BOD (mg/l) & 89,39 \\
\hline Amonia (mg/l) & 59,39 \\
\hline Fosfat (mg/l) & 66,53 \\
\hline \multicolumn{2}{|c|}{ Sumber : Sutanto, 2020 } \\
\hline
\end{tabular}

Penanganan air limbah yang akan dibuang dalam suatu perairan dapat dilakukan dengan berbagai cara yaitu secara fisik, kimia maupun secara biologi. Penerapan penanganan limbah secara biologi banyak dipilih karena merupakan cara yang efektif dan murah dengan memanfaatkan kemampuan mikrobia yang banyak terdapat di alam. [10]

Sementara itu konsep pengolahan air limbah menggunakan media tumbuhan air atau yang lebih populer dengan istilah fitoremediasi sudah lama dikenal. Akan tetapi terapi lingkungan dengan cara ini masih kurang "diminati" oleh masyarakat sebagai solusi pemecahan masalah lingkungan yang semakin lama akan menjadi permasalahan yang kronis. Di sisi lain, pengolahan limbah menggunakan bahan-bahan kimia justru membutuhkan biaya yang sangat tinggi, bahkan terkadang melebihi biaya produksi suatu produk tertentu, sehingga sebagian masyarakat lebih memilih untuk tidak melakukan pengolahan limbah terlebih dahulu sebelum limbah tersebut dibuang ke lingkungan sekitarnya. Akibatnya semakin lama terjadi penurunan kualitas lingkungan yang berdampak pada penurunan kualitas dan kuantitas produk budidaya itu sendiri. Konsep pengolahan limbah dengan prinsip fitoremediasi ini biasanya diterapkan dengan membangun sebuah ekosistem buatan yang berfungsi sebagai pengolahan air limbah, (Cit. Crites dalam Erina \& Wiyono, 2010). [11]

Seperti ditunjukan pada table II. dibawah ini, beberapa penelitian membuktikan kemampuan tanaman air dalam menurunkan parameter polutan dalam limbah domestik harus diperhitungkan sebagai alternatif system yang dapat dipilih.

Table II. Efisiensi penurunan beberapa parameter limbah domestik menggunakan constructed wetland [12]

\begin{tabular}{|l|l|c|c|c|c|c|c|}
\hline \multirow{2}{*}{$\begin{array}{l}\text { Siste } \\
\mathrm{m}\end{array}$} & Species & \multicolumn{6}{|c|}{ Efisiensi penurunan (\%) } \\
\cline { 3 - 8 } & & BOD & COD & $\begin{array}{c}\text { TS } \\
\text { S }\end{array}$ & $\begin{array}{c}\text { TD } \\
\text { S }\end{array}$ & $\begin{array}{c}\text { Nitra } \\
\text { t }\end{array}$ & $\begin{array}{c}\text { Phosp } \\
\text { at }\end{array}$ \\
\hline $\begin{array}{l}\text { Single } \\
\text { specie } \\
\mathrm{s}\end{array}$ & $\begin{array}{l}\text { Salvinia } \\
\text { molesta }\end{array}$ & $\begin{array}{c}54,1 \\
1\end{array}$ & 53,7 & & & 84,9 & \\
\hline \multirow{5}{*}{} & Thypa & 67,0 & 71,1 & 24, & & & 38,96 \\
& $\begin{array}{c}\text { angustifoli } \\
\text { a }\end{array}$ & 9 & 1 & 1 & & & \\
\hline & Pistia & 23 & 46,3 & 76 & & & \\
& stratiotes & & 1 & & & & \\
\hline & Cyperus & 75,7 & 76,2 & 32, & 26 & & 77 \\
& papirus & 5 & 5 & 6 & & & \\
\hline
\end{tabular}




\begin{tabular}{|c|c|c|c|c|c|c|}
\hline $\begin{array}{l}\text { Multi } \\
\text { specie } \\
\text { s }\end{array}$ & $\begin{array}{l}\text { Pistia } \\
\text { stratiotes } \\
\text { Limnochar } \\
\text { is flava } \\
\text { Hydrilla } \\
\text { verticillata }\end{array}$ & $\begin{array}{c}81,3 \\
6\end{array}$ & 80,4 & $\begin{array}{c}60, \\
9\end{array}$ & 81,7 & 13,09 \\
\hline & $\begin{array}{l}\text { Iris } \\
\text { pseudacor } \\
\text { us } \\
\text { Echinodor } \\
\text { us } \\
\text { palaefolius }\end{array}$ & 6,25 & $\begin{array}{c}50,7 \\
6\end{array}$ & & $\begin{array}{c}46,1 \\
3\end{array}$ & 96,3 \\
\hline
\end{tabular}

Diagram dibawah ini (gambar 4.) menunjukan selain pemilihan sistem yang efektif untuk mengolah limbah domestik, perlu dipertimbangkan faktor-faktor lain seperti biaya operasional yang tentunya akan terkait dengan kemampuan masyarakat untuk mendukung keberlanjutan operasional system. Biaya juga bisa dikaitkan dengan biaya energi yang diperlukan untuk mengoperasikan system pengolahan, sehingga perlu adanya transfer pengetahuan tentang system yang membutuhkan biaya energi yang rendah. Ketersediaan lahan dan sumber daya manusia juga menjadi faktor penting yang harus dipertimbangkan..

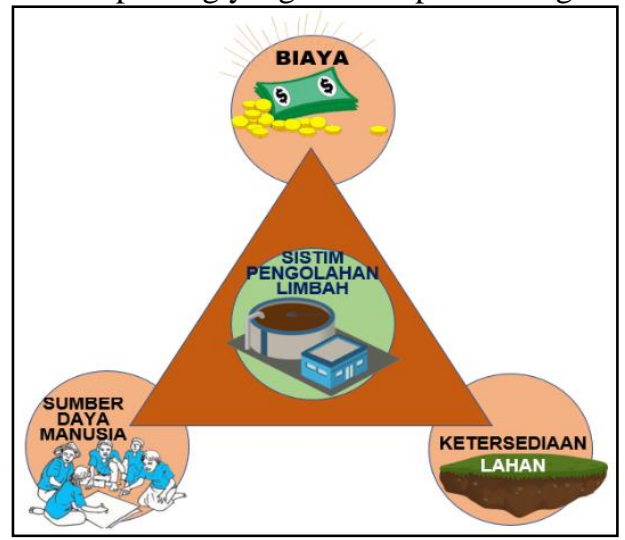

Gambar 4. Diagram faktor-faktor yang mempengaruhi pemilihan system Pengolahan Limbah

Sumber : Dokumentasi Pribadi

Ketersediaan lahan terkait dengan volume limbah yang akan diolah dan teknologi system pengolahan yang akan diterapkan. Modifikasi system pengolahan yang cocok diterapkan di lahan yang terbatas dapat diperoleh dari hasil penelitian yang mengkhususkan pengembangan system pengolahan untuk daerah dengan lahan yang terbatas. Penelitian yang sudah dikerjakan oleh penulis dapat dideseminasi lewat kegiatan pendampingan masyarakat ini sehingga hasil penelitian dapat dimanfaatkan oleh masyarakat luas dan tidak sekedar menjadi dokumen yang tersimpan. Faktor penentu lainnya adalah sumber daya manusia yang pada akhirnya akan membuat kerja / program yang akan diputuskan menjadi suatu tindakan akan dapat berjalan secara berkelanjutan dan pengoperasian system akan dapat dipelihara dengan baik. Pemilihan system harus disesuaikan dengan SDM yang ada untuk menjamin system tetap akan berjalan dengan baik.

Untuk memahami lebih lanjut suatu system pengolahan limbah diadakan studi banding ke lapangan dengan pendampingan untuk memudahkan pemahaman karena latar belakang masyarakat yang tidak/belum mengetahui tentang proses pengolahan limbah secara biologi, sehingga diskusi, pertanyaan dan rasa ingin tahu saat studi lapangan dapat terfasilitasi dengan baik.

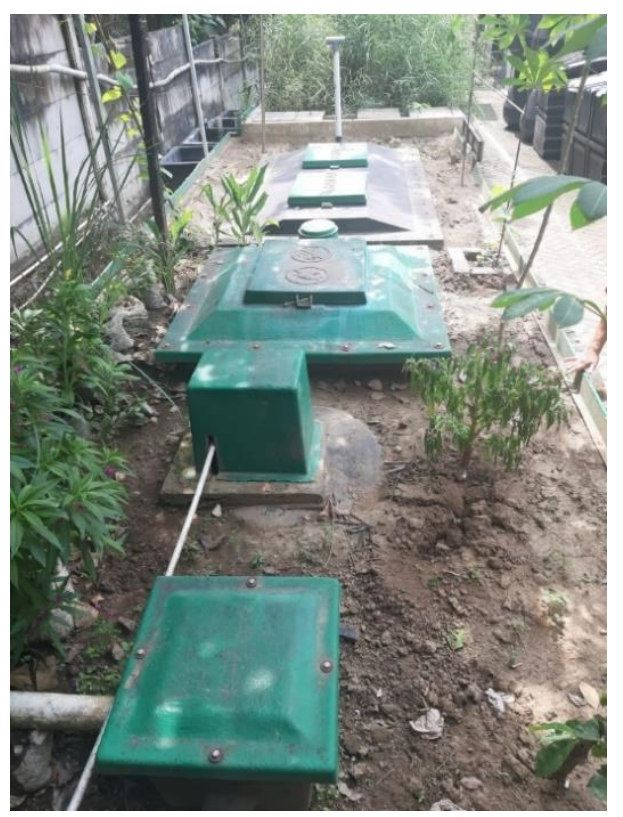

Gambar 5. Lewat studi banding ke lapangan masyarakat dapat lebih memahami contoh aplikasi sistem pengolahan limbah Sumber : Dokumentasi Pribadi

Dari hasil workshop dan FGD disepakati system pengolahan secara biologi merupakan system yang murah dan mudah untuk diaplikasikan. Demikian juga untuk mengolah limbah padat, dalam hal ini sampah organik, diinginkan dengan system biotreatment. Sementara limbah padat non organik dianggap masih dapat diatasi dengan kegiatan bank sampah yang sudah berjalan di wilayah kelurahan Sorosutan dengan tetap mencari alternatif solusi yang baru untuk mengubah sampah menjadi bahan bakar.

Untuk memperkaya pilihan, selain menerima pengetahuan lewat worshop desiminasi hasil penelitian tentang alternatif system pengolahan secara biologi serta transfer pengetahuan tentang system pengolahan biologi (gambar 7.), studi lapangan dilakukan di tempat aplikasi IMUT (Integrasi Maggot Unggas tanaman) (gambar 6). 


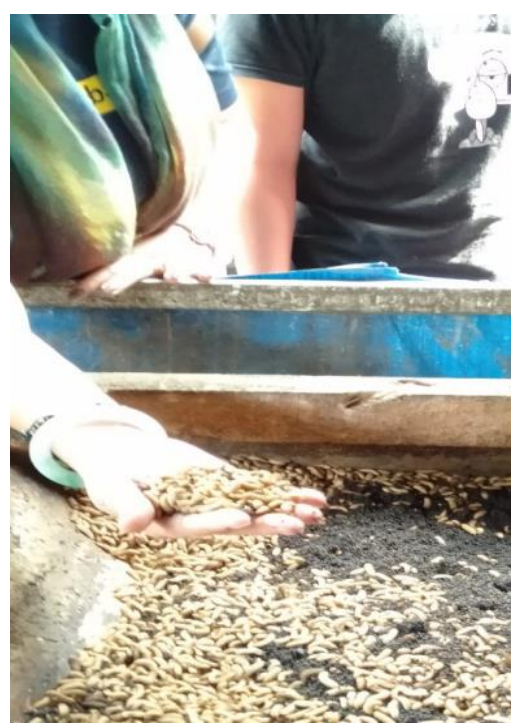

Gambar 6. Larva BSF yang diterapkan untuk menghancurkan sampah organik

Sumber : Dokumentasi Pribadi

Maggot merupakan larva dari Black Soldier Fly (BSF) yang sekarang semakin banyak diminati karena kemampuannya membantu mengatasi permasalahan sampah organik dalam waktu yang sangat cepat. Maggot juga memberikan peluang untuk dikembangkan menjadi usaha budidaya yang layak diperhitungkan dan dicoba karena kemampuan maggot BSF, sekitar $750 \mathrm{~kg}$ maggot dapat menguraikan sekitar 2 ton sampah organik dalam kurun waktu 2-3 minggu [13]. Maggot BSF sendiri juga dapat digunakan sebagai pakan ikan dan ternak unggas. Studi di lapangan ini juga membuktikan pengolahan sampah dengan BSF cukup mudah dan murah serta memberikan peluang peningkatan ekonomi masyarakat. Sementara studi lapangan aplikasi system IPAL dilakukan di SANFAB, sebuah industri yang memasarkan IPAL pabrikasi yang juga menawarkan system pengolahan air limbah secara biologi. Salah satu system yang diaplikasikan di lapangan adalah system yang sudah diperkenalkan lewat FGD dan workshop bersama pengurus masyarakat, system constructed wetland
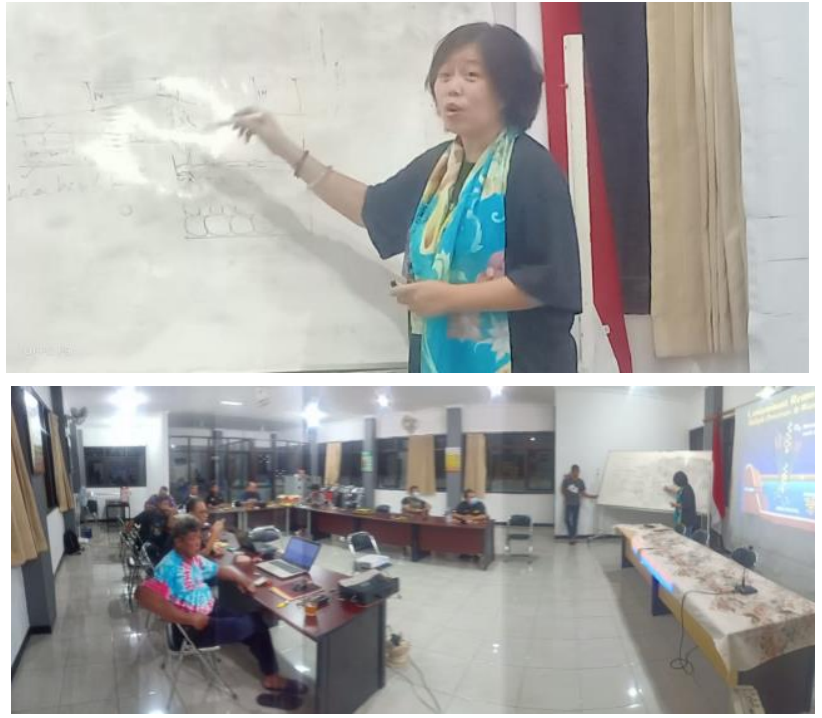

Gambar 7. Transfer ilmu Pengetahuan sebagai bagian dari tahapan pemberdayaan dilakukan lewat workshop bersama pengurus masyarakat Sumber : Dokumentasi Pribadi

\section{KEPUTUSAN / PILIHAN TINDAKAN}

Keseluruhan proses mulai dari permohonan pendampingan dari Lembaga Pemberdayaan masyarakat Kelurahan (LPMK) kelurahan Sorosutan dilanjutkan dengan dimulainya tahap identifikasi potensi dan permasalahan untuk mewujudkan gagasan pembuatan Taman Edukasi Sampah Sorosutan bersama teman-teman dari Fakultas Arsitektur dan Desain Universitas Kristen Duta Wacana hingga tahap identifikasi alternatif pilihan sistem pengolahan limbah telah dilakukan sejak Desember 2020 dan masih berlangsung sampai sekarang. Beberapa kegiatan lanjutan untuk menuju ke tahapan pilihan tindakan terkendala dan tidak dimungkinkan untuk dilanjutkan. Karena situasi pandemi yang tidak stabil terutama di wilayah kota Yogyakarta. Saat keadaan sudah memungkinkan kegiatan tahap berikutnya akan dimulai kembali.

Seperti yang tertuang dalam buku "Strategi Pemberdayaan Masyarakat" [14] ditulis bahwa pemberdayaan bukanlah merupakan sikap pemaksaan kehendak, proses yang dipaksaan atau kegiatan untuk kepentingan pemrakarsa", proses yang diterapkan untuk mendampingi gagasan pembuatan Taman Edukasi Sampah Sorosutan, dilakukan melalui beberapa tahapan untuk menempatkan masyarakat sebagai pengambil keputusan. Intervensi dari luar diberikan sebagai penambahan pengetahuan bagi masyarakat untuk dapat mengambil keputusan secara mandiri Karena partisipasi aktif masyarakat diperlukan untuk mewujudkan kegiatan 
berbasis masyarakat ini, maka disadari bahwa proses yang dilakukan membutuhkan waktu yang panjang. Keterlibatan masyarakat yang tinggi dipercaya menghasilkan tingkat kepuasaan masyarakat sebagai penerima manfaat dan menjamin keberlanjutan program yang nantinya akan dilakukan oleh masyarakat sendiri sebagai sebuah keputusan yang juga diambil oleh masyarakat itu sendiri.

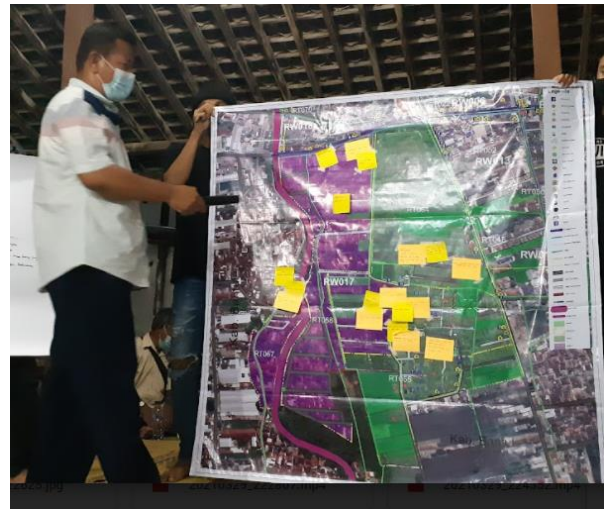

Gambar 8. Partisipasi aktif masyarakat diperlukan sejak awal proses Sumber : Dokumentasi Pribadi

\section{KESIMPULAN}

Masyarakat dilibatkan sejak tahapan awal proses pendampingan pembuatan Taman Edukasi sampah Sorosutan, yaitu sejak tahap Identifikasi Permasalahan dan Potensi Wilayah Kelurahan Sorosutan. Keharusan untuk melibatkan orang-orang sebagai warga kelurahan tersebut bertujuan untuk lebih memperhatikan hidupnya dan menambah rasa percaya diri dengan bertambahnya pengetahuan untuk mengembangkan keahlian baru dan mampuh mengambil keputusan secara mandiri untuk perbaikan yang direncanakan, diputuskan dan direalisasi oleh masyarakat itu sendiri. Model kerjasama yang dilakukan antara perguruan tinggi, Lembaga pemerintah dan masyarakat, dengan memberi kepercayaan pada masyarakat sebagai pengambil keputusan diharapkan dapat memberi dampak pada kehidupan masyarakat dan menciptakan rasa memiliki serta rasa tanggung jawab untuk mewujudkan dan menjaga keberlanjutan program yang dipilih dan diputuskan oleh masyarakat itu sendiri. Keterlibatan masyarakat sejak awal proses juga akan menimbulkan perasaan bahwa masyarakat yang mewujudkan suatu program dengan ide pemikiran mereka sendiri. Intervensi dari luar dalam hal ini dari Perguruan Tinggi pada tahap identifikasi alternatif pilihan bertujuan untuk memperkaya ilmu pengetahuan masyarakat dengan mendesiminasi hasil-hasil penelitian dan meningkatkan kemandirian masyarakat untuk mengambil keputusan. Proses pendampingan masih berlangsung dan disadari membutuhkan waktu yang panjang dengan tahapan yang selalu melibatkan masyarakat untuk mencapai keputusan yang disepakati bersama, Karena kendala situasi akibat pandemi covid, proses pendampingan sampai pada identifikasi alternatif pilihan, sementara tahap pengambilan keputusan atau pilihan tindakan belum terealisasi.

\section{DAFTAR PUSTAKA}

[1] S. Seo, T. Aramaki, Y. Hwang and K. Hanaki, "Environmental Impact of Solid Waste Treatment Methods in Korea," Journal of Environmental Engineering, vol. 130, no. 1, pp. 81-89, 2004.

[2] S. V. Golomeova S. and K. S. S. S., "Solid Waste Treatment echnologies," in INTERNATIONAL CONGRESS "MACHINES, TECHNOLOGIES, MATERIALS", Sofia, 2013.

[3] P. R. Indonesia, "PERATURAN PEMERINTAH REPUBLIK INDONESIA, NOMOR 101 TAHUN 2014 TENTANG PENGELOLAAN LIMBAH BAHAN BERBAHAYA DAN BERACUN," Kementrian Sekertriat Negara Republik Indonesia, Jakarta, 2014.

[4] P. R. INDONESIA, "UNDANG-UNDANG REPUBLIK INDONESIA NOMOR 18 TAHUN 2008 TENTANG PENGELOLAAN SAMPAH," MENTERI HUKUM DAN HAK ASASI MANUSIA REPUBLIK INDONESIA, Jakarta, 2008.

[5] G. L. Widyaningrum, "Pengelolaan Sampah di Indonesia masih Buruk, Perlu Kolaborasi dan Revolusi," National Geographic Indonesia - http://nationalgeographic.grid.id [diakses 28 Agustus 2021], 22 Agustus 2020.

[6] Tim_Korkot, "Rencana Penataan Lingkungan Permukiman Kelurahan Sorosutan, Kecamatan Umbulharjo tahun 2017-2021," Unpublished Report, Yogyakarta, 2016.

[7] A. U. Zaman, "ComparativeStudy of Municipal Solid Waste Treatment Technologies Using Life Cycle Assement Method," International Journal of Environmental Science \& Technology, vol. 7, no. 2, p. 225-234, 2010.

[8] A. I. Stefanakis, "Constructed Wetlands for Sustainable Wastewater Treatment in Hot and Arid Climates: Opportunities, Challenges and Case Studies in the Middle East," Journal Water, vol. 12, no. Wetlands in Action: Sustainable Water Management and Resource Recovery, pp. 1-24, 2020.

[9] H. B. Sutanto, "Efektivitas Pengolahan Limbah Domestik Menggunakan Sistem Pengolahan Model Vertical Constructed Wetland menggunakan Tanaman Echinodorus palaefolius Berdasarkan Kedalaman Sistem," Unpublished Report, Yogyakarta, 2020 .

[10] H. Insam, I. H. Franke-Whittle and M. Goberna, Microbes at Work, Heidelberg: Springer, 2010.

[11] R. Erina and E. Wiyono, "Domestic Wastewater Treatment using Constructed Wetland as a Development Strategy of Sustainable Residential," in International Conference on Environment, Energy and Biotechnology, Singapore, 2012.

[12] H. B. Sutanto, "“Scaled Constructed Wetland, An alternative Waste Water," in International Joint Conference, SENVAR, INTA, AVAN 2015, Johor, malaysia, 2015.

[13] Sugiharto, "Budidaya Maggot BSF layak dilirik," http://agroindonesia.co.id/ [Diakses 28 Agustus 2021], pp. 1-6, 3 November 2020.

[14] H. Hikmat, Strategi Pemberdayaan Masyarakat, Bandung: Humaiora, 2013. 